\title{
Cultural and Semiotic Strategies of Constructing Indigenous Northern Ethnicity in Art (Based on the Yakut Art School)
}

\author{
Nataliya N. Seredkina* \\ Siberian Federal University \\ 79 Svobodny, Krasnoyarsk, 660041, Russia
}

Received 22.11.2014, received in revised form 03.12.2014, accepted 05.02.2015

The article studies cultural and semiotic strategies of constructing indigenous Northern ethnicity in art on the basis of the Yakut art school development research and analysis of paintings by artists of the school. It defines peculiarities of each period of the Yakut art formation, reveals the trends of national school development within the stream of common art history. It suggests authorial systematization of paintings by the Yakut artists. Works are grouped by themes. These are paintings, the cultural and semiotic forms of which reveal the spiritual world view of the Yakut; pieces representing the concept of way, the road of life a human walks along; portraits, the visual appearances of which represent certain types of cultural heroes; still lives, representing the most significant items of the Yakut culture. It outlines the development vector of the modern Yakut art, which is the tendency for re-consideration and adaptation of the ethnic memory of the nation for the new globalized world context.

Keywords: cultural and semiotic strategies, construction, indigenous Northern ethnicity, national art, Yakut painting, Yakut artists, Yakut art school, ethnocultural values.

Research area: culture studies, art history.

\section{Introduction}

The question of ethnical diversity of the society and settlement of international relations takes up a significant place in the modern national policy agenda. In these issues a great role is played by local authorities running regional programs on carrying out multiple events intended to boost national development and expand intercultural cooperation between the peoples resident in the Russian Federation. The most urgent are the projects targeted at symbolic reproduction of ethnical identity of various ethnical group members. Today, the practice of celebrating national holidays, making television coverage on ethnical topics are becoming more and more popular. Such practices make up actual themes for scientific researches, while symbolic "field" (P. Bourdieu) of the national art, and the Yakut art school in particular, remains unstudied in the context of ethnic theme construction. We may mention a series of works, dedicated to the analysis of ethnofuturism as a trend of modern art (Gartig, 2006; Matochkin, 2009; Nekhviadovich, 2010; Pavlova, 2007). Among researchers of the Yakut painting we should remark Potapov I.A., who wrote the fundamental works which

(C) Siberian Federal University. All rights reserved

* Corresponding author E-mail address: NevolkoN@yandex.ru 
now make a base for modern researches by: Borisova A.A., Zlatkevich L.L., Kuz'mina L.A., Chervonnaia S.M., Lutsenko Iu.V., Timofeeva V.V. and others. Dissertations by Vlada Vladislavovna Timofeeva "World View in Painting and Graphics of the $20^{\text {th }}$ Century's Yakutia" (2006) and Iuliia Vladimirovna Lutsenko "Artistic and Aesthetic Self-Conscience of the Yakut Painters at the Turn of Centuries" (2009) are especially outstanding.

Dissertation by Timofeeva V.V. "World View in Painting and Graphics of the $20^{\text {th }}$ Century's Yakutia" is based on the comparative historical approach to art work analysis. The author studies motives and appearances, common both for professional art and folk culture, analyzing painting and graphics by the Yakut artists created from the 1920-s to 1990-s.

Dissertation by Lutsenko Iu.V. "Artistic and Aesthetic Self-Conscience of the Yakut Painters at the Turn of Centuries" was the first one dedicated to the ethnical aspect in the Yakut culture. The dissertation is based on painting and graphics by the Yakut artists. The major attention of the author is concentrated on revealing peculiar features of ethnonational artistic and aesthetic conscience of the artists. According to the author, this topic is especially urgent at the beginning of the new millennium, as during the last years both creators and recipients of art have greatly changed, while the forms of art and their presentation have also gone through a great transformation.

The objective of the present research is to analyze cultural and semiotic strategies of constructing indigenous Northern ethnicity in art based on the analysis of the Yakut painting development and of paintings by artists from the Sakha Republic.

The research is based on methodological principles of the cultural and semiotic approach, developed by such scholars, as J.C. Alexander, F.C. Smith, C.J. Geertz, Yu.M. Lotman, G.N. Lola, E.A. Orlova, C.S. Pierce. Constructivist ideas by such theorists as P. Bourdieu, F. Barth, V.S. Malakhov, V.A. Tishkov and others were considered in formulating the author's concept of art, composing the fundament of this research. We suggest regarding art as a cultural and semiotic construct, creating social senses in individual and collective consciences. As a secondary constructing system, art actualizes existing and functioning primary constructs, embodying ethnocultural values, in its cultural and semiotic forms (Koptseva, Seredkina, 2013).

The work uses both theoretic and empiric methods. It is the analysis of scientific literature on social philosophy, social anthropology, culturology and art criticism, dedicated to the present topic. Among the most actively used methods there are: observation, analysis, interpretation of the Yakut visual art works.

\section{The Yakut visual art development dynamics}

The objective of this paragraph is to analyze the development dynamics of the Yakut visual art as one of the most distinctive ethnical art schools.

The Yakut art school development may be described as three stages. At the first stage (late $1^{\text {th }}-$ early $2^{\text {th }}$ centuries) the Yakut visual art was mostly based on Russian icon-painting school traditions. It is known that back in the $17^{\text {th }}$ century in the North of Russia the so-called Zaonezhskaya icon-painting school was founded. The school developed Novgorod icon-painting traditions in the local environment (Zhukovsky, 2007). According to historical data, it was also in the $17^{\text {th }}$ century that the first contact of the Yakut with Russians was registered. At the same time, the Yakut lands were joined to Russia.

As a consequence of such processes that happened between two absolutely different ethnicities, Christianity began to spread among local Yakut population. From this time, the Yakut 
people began to absorb Russian culture; in other words, the it was the beginning of assimilation with Russian population. Starting from the $18^{\text {th }}$ century, in Khangalaassky Ulus of Yakutia a great number of churches was built. Consider that until the end of the $18^{\text {th }}$ century Christianity in Yakutia was preached by mostly Russian residents. As a rule, churches in the Yakut fortresses (or "ostrogs") were built for Russian people. This is why at first in Yakutia only imported Russian icon paintings were common, and later, starting from the late $19^{\text {th }}$ century, new iconic paintings, created by both local Yakut and Russian painters, began to appear. This phenomenon witnesses the process of penetration of another culture's world outlook into the Yakut culture, which, in this case, was that of Russians.

What was adopted? First of all, the icon painting themes: Theophany, along with other iconographic patterns, such as "Tender Feeling" and "the Sign", known in several variants in Russia. The most distinctive icons of the mentioned iconographic patterns in the art of Ancient Russia are the front face of "Our Lady of the Don" (approx. 1392) and "Our Lady Panhagia" (first quarter of the $13^{\text {th }}$ century). Joint work of the Russian and Yakut masters is also known for the green background icons. Painting such icon backgrounds was peculiar both for Novgorod and Moscow schools of icon painting. Studying the specificity of icons displayed at the Yakut museums, the first thing that meets the eye is the transformation of composition in placing the Virgin Mary and Baby Jesus within the icon space. In the Yakut icons the Virgin Mary and Baby Jesus are depicted as a mirror reflection of the Old Russian icon "Our Lady of the Don", typical of Moscow icon painting school, Theophanes the Greek or other painters of his circle (exact authorship of the icon is still unknown) in particular. Moreover, the Yakut masters introduce some changes into the Tender
Feeling icon painting pattern as well. Thus, the Virgin Mary and the Baby are depicted distant from each other: there is a visual separation line between them. The hands of the Virgin Mary are supporting the body of Jesus Christ, at the same time pushing Him apart from Her. Thereby, $\mathrm{He}$ is portrayed as ready to enter the world for salvation. There is no doubt that the presence of the Yakut masters in icon painting process is also manifested in the desire of the painters to convey the autochthonous ethnic features in the face of the Virgin Mary.

This way the starting point of the Yakut painting formation was icon painting. The main school for the Yakut art was Russian icon painting tradition, mainly that of Moscow and Novgorod schools of the $12^{\text {th }}-15^{\text {th }}$ centuries (themes of Theophany, icon painting patterns of the Tender Feeling and the Sign, colour symbolism).

The second stage is associated with the emergence of proper national art of the Republic of Yakutia (1910-1940).

Regarding the preconditions of the Yakut art formation, it is evident that the development of the Yakut art school is based on Russian cultural tradition. It is evident not only from the joint works of visiting Russian icon painters with the Yakut masters, but also from the fact that the first Yakut painters, Ivan Vasilyevich Popov (1873-1945) and Mikhail Mikhailovich Nosov (1887-1960), were descendants of local Russian residents. Moreover, I.V. Popov, just like all the following professional artists, was educated at a Russian school, at the private studio of A.V. Makovsky, professor of High College of Art of Saint Petersburg Academy of Art.

Obviously, Russian origin and Russian art school left their mark in the works of painters belonging to the "initial" stage of Yakut visual art development. For example, the space of the painting "Yakutsk of the Late $17^{\text {th }}$ Century" by I.V. Popov (1928) depicts a fortification with 


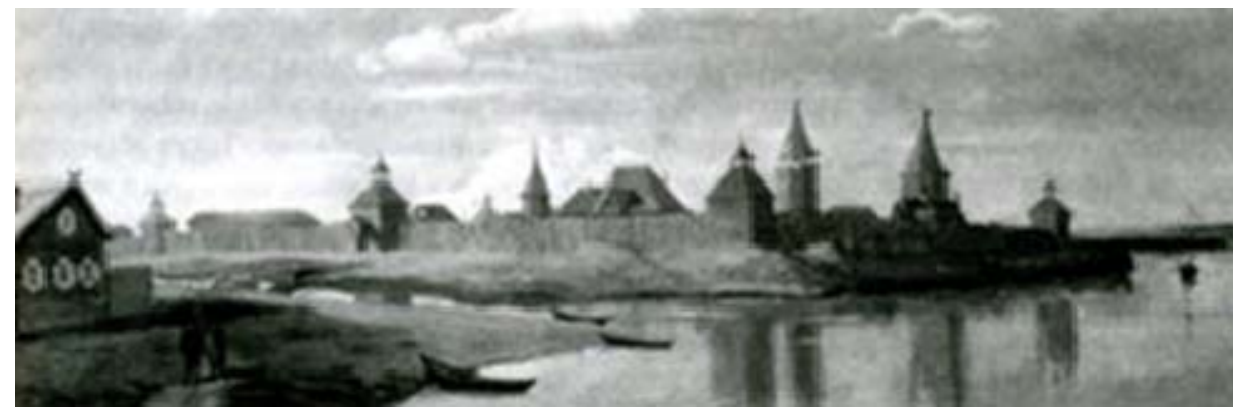

Fig. 1. Popov I.V. Yakutsk of the Late 17th Century. 1928

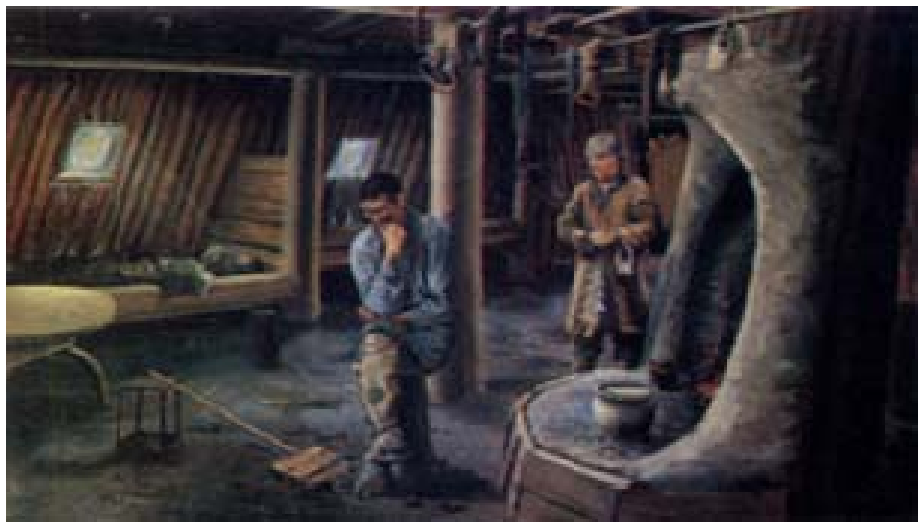

Fig. 2. Nosov M.M. In a Poor Man’s Yurt. 1936

some watchtowers, resembling a Russian ostrog (fortress), an architectural construction typical for Russia of the $13-18^{\text {th }}$ centuries.

At the second stage (1910-1940) of its development the Yakut art school gets less dependent on the Russian cultural influence. It obtains the features of a national, independent, separate school. The artists who developed the national trend in visual art were painters and graphic artists M.M. Nosov and I.D. Izbekov (1909-1996). The works of these painters were not determined by the classical art education limits. Both of them were self-taught. M.M. Nosov engaged himself in independent research of the Yakut ethnography, at the same time studying at the High Liberal Workers' School in Saint Petersburg. Returning to Yakutia, he began his teaching career simultaneously with painting. In the year 1915, with the assistance of E.M. Yaroslavsky, who managed the Yakut Museum of Regional Studies from 1950 until 1917, the first art exhibition displaying the artist's works "Yakut Still Life", "The Ancient Settler Say-Sary", "Yakut Woman and Tungus Woman" was organized. The exhibition gave a great push to the national art. The peculiarity of works by M.M. Nosov and I.D. Izbekov is their authors' desire to depict the uniqueness of the Yakut ethnical culture. The artists turn to the motives characterizing the Yakut culture: folk customs and traditions, yurts as national dwelling of the ethnocultural group, traditional crafts and everyday routine objects. For example, the most typical of their paintings are: "In a Poor Man's Yurt" (1936), "Yakut Still Life" (1942), “Ancient Yakut Dance” (1946) by M.M. Nosov; 
“Kolkhoz Flock” (1947), "Horse Racing” (1951), "The Herd" (1959), "In the Tundra" (1963) by I.D. Izbekov.

One of the first painters to make a contribution into the formation of the professional Yakut art was Petr Petrovich Romanov (1902-1952). He was the first national painter to be recognized as "the emblem of the Yakut visual arts" (Timofeeva, 2006, p.33). Petr Petrovich was one of the organizers of the Yakut painters' association in the late 1930-s - early 1940-s and the founder of the Yakut School of Arts. In the year 1945, upon the artist's incentive, the Decree of the Council of People's Commissars of Yakut Autonomous Soviet Socialist Republic "On Opening a School of Arts in the City of Yakutsk" No.233 dated 02.04.45 declared the foundation of the Yakut School of Arts. Since that time, the Yakut painters had the opportunity to develop their skills on the professional level. This was the beginning of a new stage in the Yakut visual art development, the stage based on professional approach to creating visual art objects.

The third stage of the Yakut visual art development is connected to the development of professional art school (1950-s - 1980-s).

The 1950-s were the years when the first graduates left the walls of the Yakut art school; many of them continued their education at various educational institutions of the country. In the 1960-s the Yakut art experienced a significant rise connected with the arrival of a large group of talented artists educated in Moscow, Leningrad and other cities of the Soviet Union. This was when the basic painting genres were shaped. The artists worked in such genres, as portrait (S.L. Alexandrov, M.V. Lukin, A.N. Osipov, L.A. Kim etc.), landscape (E.M. Krylov, N.M. Zasimov, A.P. Sobakin, N.G. Sirotkin, V.G. Petrov, A.N. Osipov etc.), genre painting (A.N. Osipov, E.I. Vasilyev, F.S. Zhegusov, I.E. Kapitonov, M.V. Lukin, N.A. Pavlov etc.).
The genre system provided the artists with wider range of tools for expressing their ideas, connected with the Yakut culture, in their artistic works.

In the mid 1970-s the genre painting occupied a prominent place in the painting system. In this type of painting such artists of the 1970-s - 1980-s, as A.N. Osipov, E.I. Vasilyev, I.E. Kapitonov, M.V. Lukin and others strived to convey the sophisticated spiritual world of the Yakut person, to depict the ethnical peculiarities of the Yakut life. Taking up the heritage of the first generation artists (1920-1940-s), one of the first Yakut Art School graduates (1950), and later the graduate of painting department of V.S. Surikov Moscow State Art Institute (D.K. Moschalsky studio, 1956), Mikhail Vasilyevich Lukin (born 1929) turns to genre painting to convey the values of the Yakut traditional occupations. He creates his paintings with the impressions from his trips around the North Polar regions. These are such paintings, as "In the Kolyma Valley" (1957), "Reindeer Racing” (1961), "On the Way" (1962), "Meeting Along the Way", "The Indigirka Fishermen" (1963) etc. The etudes, drafts and paintings of this cycle affirm the original Yakut concept of living.

The portrait genre was preferred by S.L. Alexandrov ("Portrait of Reindeer Breeder N. Kurilov", 1966), L.A. Kim ("Portrait of the Honoured Artist of YASSR M.V. Zhirkov”, 1962), V.G. Petrov, I.E. Kapitonov, Z.K. Kurchatova and others, who chose to visualize certain personalities of the Yakut lands. Here we also observe the artists' interest to personality, let it be historical or contemporary, and to the artist himself. At this stage of the Yakut visual art development various types of portraits were formed: children's portrait, self-portrait, representative and chamber portraits. All of them manifest a peculiar trait of ethnocultural character of the Yakut: the selfvalue of each person, regardless of its social 
status. Each representative of the Yakut ethnos is equally significant and valuable.

Therefore, the 1950 - 1980-s of the history of the Yakut visual art development are characterized by formation of the Yakut art school on the professional level. Such development manifested itself in shaping up the genre system of painting, which enabled the artists to visualize different aspects of the ethnos' life in their works of art.

The fourth stage of the Yakut visual art development is the modern period of the Yakut visual art development (1990 -2000-s).

Since the year 1990, which means, since the declaration of state sovereignty of Yakutia, a new, different stage of visual art development begins; this stage is mainly associated with the appearance of new generation artists, free from the traditions of the previous decades, therefore, contributing new methods of expressing the ethnos' world outlook into their art. In the year 1993, the new generation created and artistic association "Flogiston": the name for it, translated from Greek, means "combustible, flammable". The association was created upon the incentive of M.V. Khanda, O.A. Rakhleeva, O.A. Skorikova, S.V. Ivanova with the support of their allies from the Yakutia Artists' Union: A.L. Sorgoeva, E.K. Atalasova, G.E. Okoiomova, I.A. Mekumianova, N.E. Fedulova, L.L. Popova, T.E. Shaposhnikova, Zh.P. Khungeeva, E.P. Romanova. In different years, the union was also joined by I.E. Kapitonov, V.S. Parnikov, E.P. Savvin, A.D. Vasilyev, G.N. Reshetnikov, M.G. Starostin (Lutsenko, 2011). The majority of "Flogistoners" got the diplomas of professional education at art institutes of Moscow, Saint Petersburg, Krasnoyarsk, Vladivostok. "Flogiston" is not a homogenous art stream. It gathered different creative individuals, free thinking personalities with different life, art and professional experience. All artists of the association work in different styles, let it be abstractionism, realism, primitivism. They all perceive themselves not only as representatives of the Yakut art, but as a part of the universal art union of the late $20^{\text {th }}$ century. It created their desire to get rid of regional boundaries and to use art for expressing themselves in the issues urgent for the modern humankind. Their striving for a cultural dialogue brought the Yakut artists to participating in both Russian and foreign exhibitions. In the year 2008, in Yakutsk, an modern Yakut art exhibition was opened under a symbolic name "Koleso" ("The Wheel"). As exhibition name, in many cases, reflects its contents, in this situation we may also speak of the meaning hidden in the title chosen for the event. In its symbolic meaning, a wheel stands for the idea of eternal movement of the universe. This is the main idea of works by Andrei Chikachev, Marianna Lukina, Anna Osipova, D’ulustan Boytunov, Semion Prokopyev, the participants of the exhibition. In the year 2009 another exhibition of graphic, painting and applied art by the Yakut artist was opened in the Polish city of Gdansk. The exhibition presented works by ten Yakut artists well-known in Russia. Among them there are: Andrei Chikachev, Olga Skorikova, Evdokia Romanova, Mikhail Starostin and Tuyaara Shaposhnikova. In 2011, an exhibition of the Yakut artists was organized within the framework of modern art exhibition "International Artexpo 2011", held in the USA, in order to popularize the indigenous painting of this multinational Northern region. It displayed some paintings by Andrei Chikachev, copper-plate engravings by Mikhail Starostin, collages by Valery Bessonov, nude-art by Mikhail Simonov. In the same year, in Moscow, the art exhibition "The Olonkho Land2011", presenting the uniqueness of the Yakut lands, was opened. Since 2008 and until present time "ARkT-Navigation" project, for artists to represent the modern art of the Sakha Republic, has been held. Often artists gather into unions, creating works under the same idea. In the year 
2014, exhibition "The Lena River. Ayaansuola" of the Yakut artists N.V. Nikolaeva (born 1964) and T.E. Shaposhnikova (born 1967) was held at the Urals, Siberia and the Far East branch of Krasnoyarsk Russian Art Academy. Their works are united under the same philosophic idea of way, expressed by motives based on ethnic peculiarities of the nations, resident in the Republic of Yakutia.

This way, in the early $21^{\text {st }}$ century the Yakut art strives to integrate into the common cultural space of the world more than ever. At the same time, entering the universal process of cultural development did not result in a loss of national originality of the Yakut art school. On the opposite, getting beyond the boundaries of the republic territory helped the artists to actualize the significance of the cultural values of their nation, ethnos, and culture as a whole. The works by the Yakut artists fits the typical tendency of modern regional art, concerning the artistic and philosophic self-expression within conventionally symbolic forms of ethnic conscience.

\section{Works by the Yakut painters} as a cultural and semiotic space

\section{for representation of ethnocultural values}

This paragraph is dedicated to cultural and semiotic analysis of visual art works by the Yakut artists. The target of the analysis is to reveal the strategies of constructing indigenous Northern ethnicity in the symbolic "field" of national art. The empiric base for the research is the paintings created by the Yakut artists throughout the whole period of the Yakut art school development (19302010-s). Let us emphasize, that the major attention was concentrated not on the time of creating this or that piece, but on its meaningful part, sign and semiotic forms, the analysis of which allowed the author to systematize works of art according to their representation of ethnocultural values. By "ethnocultural values" we understand such secondary constructs which symbolically bring the artist and the viewer back to their roots, to their original cultural traditions.

The first block consists of the works embodying the spiritual world outlook fundament of the Yakut nation. These are works of art with sign and semiotic forms representing religious rituals, typical of the Yakut culture. As a rule, they depict the motives of magical manipulations performed by a shaman, the bearer and protector of the national religion, shamanism; the motives associated with traditions and customs, kept by representatives of the Yakut ethnos, and the motives dedicated to natural elements. Representatives of this group are works by M.M. Lukina "Triptych Ysyakh" (1993), "The Desired Coast" (1998), M. Khandy "Shaman Speaking to Spirits" (1996), N.V. Nikolaev "The Shaman" (2000), M.M. Nosov "Ancient Yakut Dance" (1946), K.P. Gavrilyev "Algys” (1997), A.A. Osipova "Northern Celebration" (2010), T.E. Shaposhnikova "Ysyakh" (2012) and others.

The artistic space of painting "The Desired Coast" by M.M. Lukina (1998) presents the major ritual of shamanism, "kamlanie" (shamanistic ritual).

On the basis of traditional world outlook of shamanism religion, we may interpret the character, sitting in the left corner of "The Desired Coast", as a shaman, holding a tambourine - a musical instrument, used as an integral "tool" of "kamlanie" ritual. The silhouettes of the shaman's body copy the semi-circle of the tambourine, thereby conveying the idea of the shaman's merging with the tambourine sounds. This way he is depicted absorbed into the shaman mystery state. According to the Yakut beliefs, during ritual the Yakut shamans would call a series of their personal assistant spirits besides their protector spirits. A part of such mythological characters is usually described as "invisible people". In the analysed work of art, the figure, dancing by the 


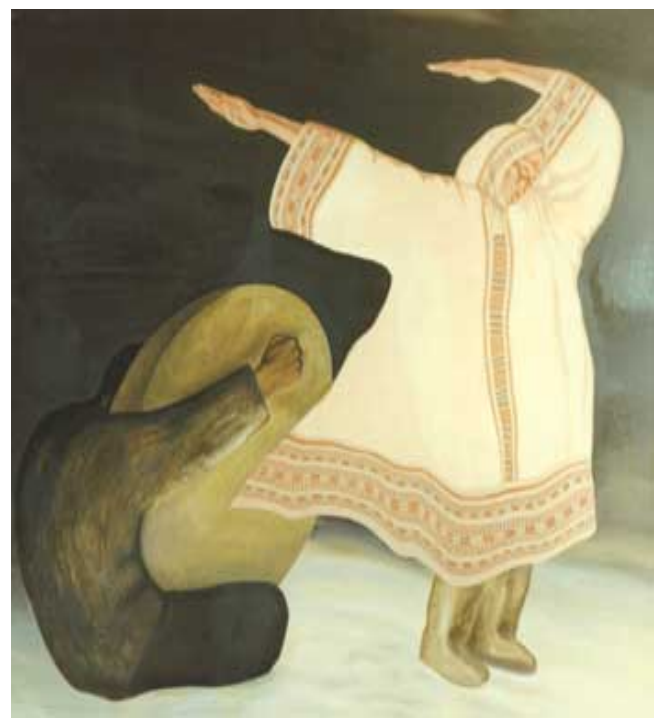

Fig. 3. Lukina M.M. The Desired Coast. 1998

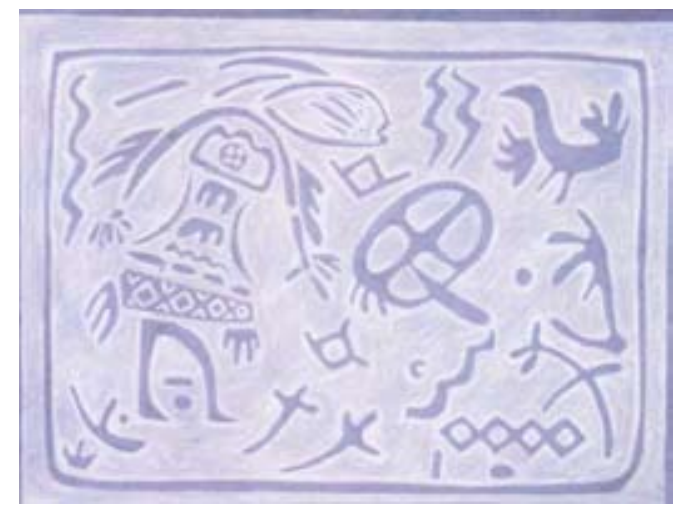

Fig. 4. Khandy M. Shaman Speaking to Spirits. 1996

side of the shaman, may also be interpreted as an artistic way to express the inner state of the shaman as ecstasy, flying across the worlds of the Universe. There is no coincidence that the female figure is depicted with her arms wide open, as though imitating the flight of a bird.

Works by M. Khandy represents a different artistic language in depicting the major ethnic religion, shamanism. It is the language of symbols, of "prehistoric" signs expressing the talks of the Yakut spiritual culture bearer, the shaman, with the senior creatures. The authors thereby emphasize the external characteristics of this religious ritual, underlining the spiritual element, the basis of shamanism, as all the processes typical of this cult are usually performed at the spiritual level, invisible for the eyes. Here the symbol language acts as the most acceptable form of expressing spiritual values of the national Yakut religion.

Triptych by M.M. Lukina is created to express the world outlook ideas of the Yakut concerning their connection to the Tree of Life. In the artistic space of the left part of the triptych we can see 

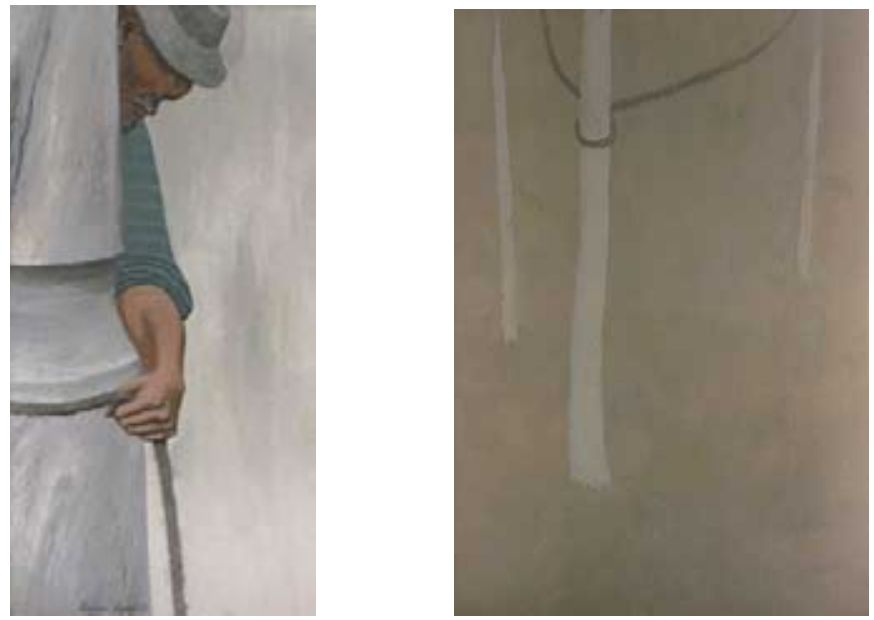

Fig. 5, 6. Lukina M.M. Triptych Ysyakh. Left part. The Old Man; Central part. The Birch. 1993

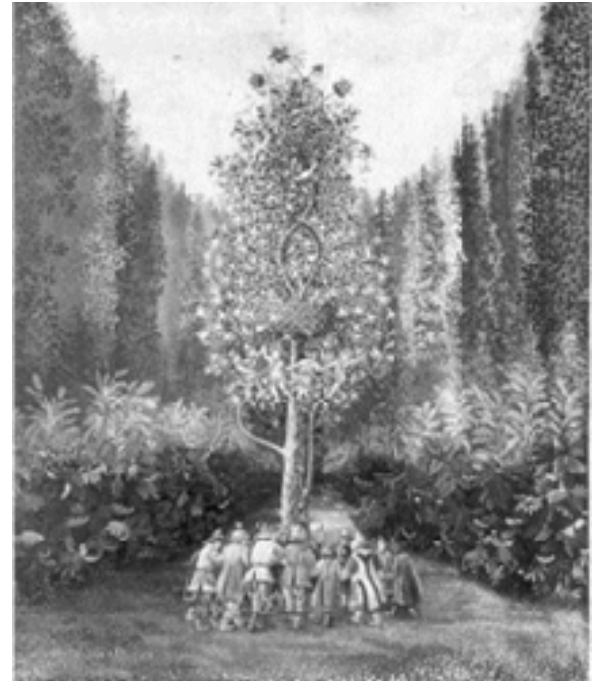

Fig. 7. Nosov M.M. The Ancient Yakut Dance. 1946

the ritual process of tying a rope around a tree trunk, which was a part of celebrating Ysyakh (traditional Yakut New Year celebration). In the central part of the triptych there is a hanging pillar with a rope tied around it. Symbolically, it expresses the idea of connection between the ethnos and the axis of the Tree of Life, the sacred centre, around which the ethnos performs its ritual round dance at the Ysyakh celebration.

A different aspect of the religious ritual is presented in works by M.M. Nosov ("The Ancient

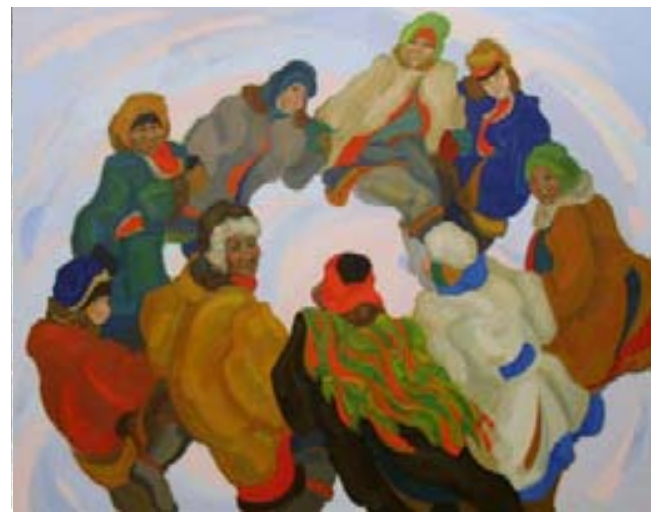

Fig. 8. Osipova A.A. The Northern Celebration. 2010

Yakut Dance", 1946) and A.A. Osipova ("The Northern Celebration”, 2010).

The artists turn to the wide-spread Yakut round dance called osuokhay. According to the Yakut, their ritual dances are the cultural phenomena intended to adapt to the natural environment and protect the people from its evil powers. By performing the round dance, the people clear their sacred space from the filth of Chaos and model a new, pure space. Moreover, the round dance was considered to possess a 
magical ability to reach the distant "alien" world. And if the work of M.M. Nosov presents, more likely, the moment of inner concentration of the dancers on the ritual they are about to perform (the characters are depicted as static, looking inside the circle), then in the artistic space of "The Northern Celebration" by A.A. Osipova the characters are dancing and moving. The sign and symbolic forms of the painting express, therefore, the idea of motion, eternal circulation of life.

The artistic space of painting "Algys" by K.P. Gavrilyev presents characters performing the ritual of blessing, addressing to the presiding deities. The compulsory symbol of this ritual, according to the Yakut beliefs, is the fire, representing the spirit of nature, an intermediary between people and gods. It is a custom of the Yakut ethnos to feed and treat fire, which is a sign of begging gods for prosperity. It is no coincidence that the sign forms of the painting represent three characters, marching one after another; two of them are carrying vessels, which is a sign of performing the traditional ritual of sacrifice to the spirit of fire. The figure of a white horse in the upper part of the composition takes up less space on the canvas than the characters engaged in the ritual. The horse is depicted walking in the same direction as the characters, which characterizes it as a protector horse, accompanying people on their way of bringing gifts to gods, asking for blessing. The sacredness of the depicted scene is enhanced by using the technique of icon painting, which is creation of a plain image. Therefore, the cultural and semiotic forms of the painting (fire, vessels, marching, horse) embody the religious world outlook of the Yakut ethnos, which is based on the tight bond between the people and the gods.

The relation to nature, and the Lena River in particular, which acts as a "character" in many paintings of the Yakut painters, is of the same significance for the Yakut ethnos. The whole history of the Yakut is closely connected to this great River. It is worshipped, it is glorified, named Iitiller Ebybit - the Life-Giving Foremother. It is associated with the feminine, maternal element of natural power, of the whole Universe, creating life and giving it to all the creatures. According to legends, it was the River Lena on which the forefather of the Sakha people Ellei came to their

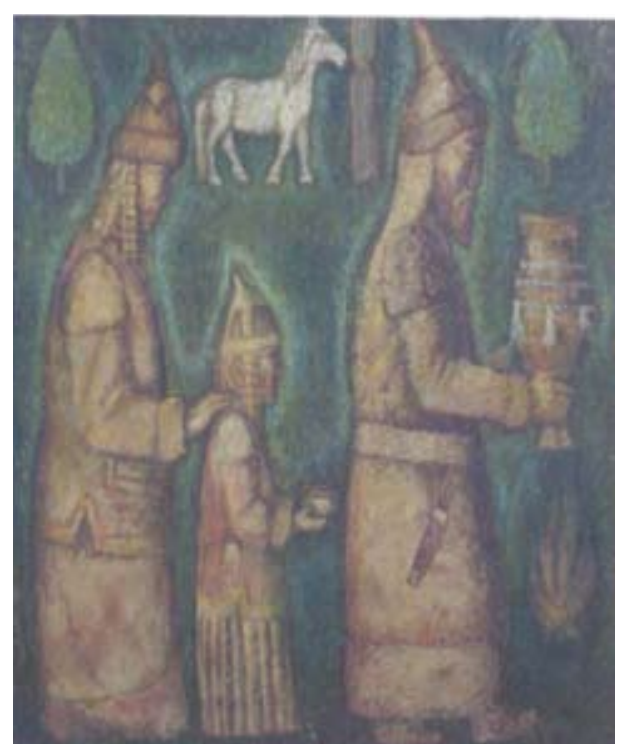

Fig. 9. Gavrilyev K.P. Algys. 1997 


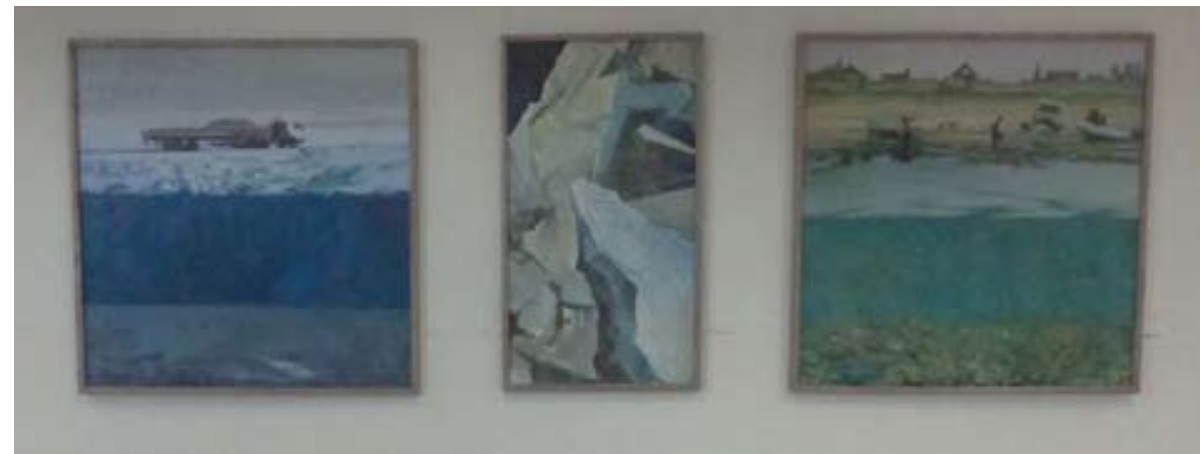

Fig. 10. Nikolaeva N.V. Triptych "The Lena River": Winter. Ice Drift; Spring; Summer. 2010-2013 (titles of paintings listed from left to right, correspondingly). Photo by N.N. Seredkina

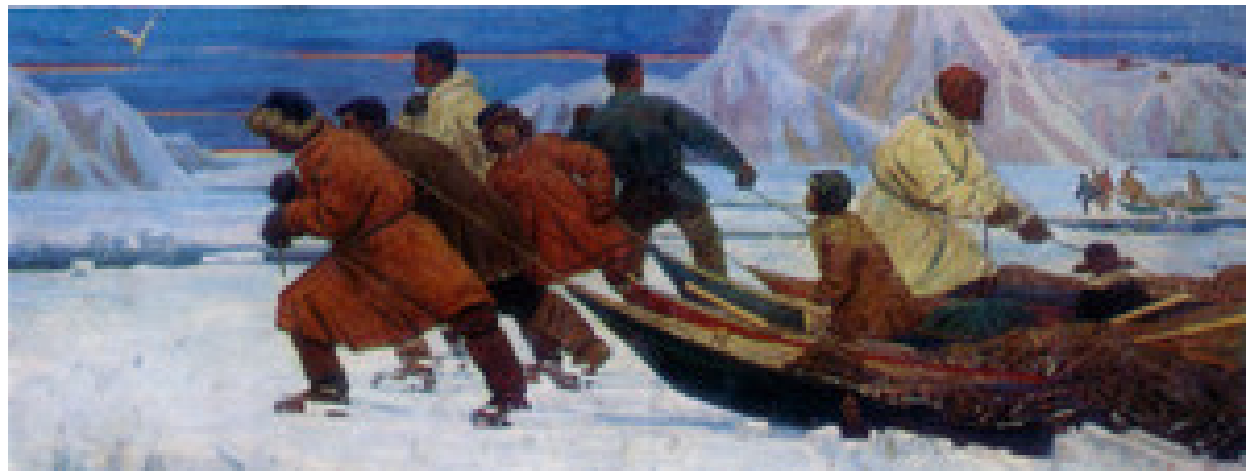

Fig. 11. Lukin M.V. Indigirka Fishermen. 1963

lands. One of the typical works dedicated to the theme of nature is triptych "The Lena River" by N.V. Nikolaeva (2010-2013). The triptych consists of paintings "Summer", "Ice Drift. Spring", "Winter".

The second group of works is represented by paintings with the sign and semiotic forms embodying the idea of way, the road of life human walks along. The idea is expressed through depiction of motives associated with the traditional working chores of the Yakut. As a rule, those are narrative paintings. Representatives of this group are paintings by I.D. Izbekov "The Kolkhoz Flock" (1947), M.V. Lukin "Indigirka Fishermen" (1963), N.M. Zosimov "To the Road" (1987), cycles by A.A. Osipova "Way of Life" (2010), “The North" (2010) etc.
The artistic space of the painting "Indigirka Fishermen" (1963) presents a group of fishermen, pulling their fishing nets. The fishermen are depicted as one whole. They are united by the general determination, orientation into the depth of the artistic space of the painting, a common burden, a common target. In their colours, the figures of the characters wearing warm-toned clothes, contrast with the artistic space of the painting, which is the cold mountain landscape. Moreover, the contrast is reached by a special composition technique. The vertical lines constituting the figures of the characters are opposed to the horizontal lines visually forming the clouds and the crack on the ice. Such compositional opposition expresses the idea of confrontation, struggle between 
human and nature elements. It is a hard way the human goes through during his life. There is no coincidence that the characters are depicted in a "stepping" posture, pulling the heavy burden of their fishing net. In this way of life the human has to be strong-hearted. The idea is supported by the fact that the characters of "Indigirka Fishermen" are presented in the background of a rock, the power, endurance and hardness of which is extrapolated on the spiritual features of the human and the ethnos as a whole. Moreover, a great significance in revealing the ethnocultural element of the Yakut ethnos belongs to the tendency of putting winter as a distinctive element of any painting's artistic space of. Winter is the season which requires certain spiritual effort to bear this most severe and long period of life. Therefore, the artistic space of the painting represents the idea of spiritual strength of the people living under severe conditions of the Extreme North.

One of the main characters of paintings by the Yakut artists is a reindeer. The Yakut, just like many other peoples, think of a reindeer as a sacred animal. It is glorified as the most valuable pray. However, the reindeer cult had more than hunting and reindeer-breeding significance in the life of the Yakut. Due to annual renovation of its horns, reindeer became a symbol of renovation, revival, fertility of human and nature as a whole. In one word, all life of people living in the North is connected to this animal.

In paintings by A.A. Osipova reindeer is depicted close to human (silhouettes of the animal cross with the silhouettes of the characters, paint strokes are of the same, cold tones). Closeness to human ascribes a characteristic of a companion to this animal. Significance of reindeer as an animal with a special status recognized by the Yakut is enhanced by the fact, that frequently reindeer is the only character in the artists' paintings. A typical example is diptych "Reindeer" by N.V. Nikolaeva (2013). The artist turns to depicting the sacred animal using certain symbolic signs. It is a specific way of communication with the viewer, forcing him to pay attention to the sacral functions of this animal.

The third block is formed by paintings of portrait genre. This genre was preferred by S.L. Alexandrov ("Portrait of Reindeer Breeder N.Kurilov", 1966), M.N. Innokentyev "Portrait of a Hunter" (2005), L.A. Kim ("Portrait of the Honoured Artist of YASSR M.V. Zhirkov", 1962), F.G. Makarov "At the Reindeer Breeders of Oymyakon" (2003), A.N. Osipov "National
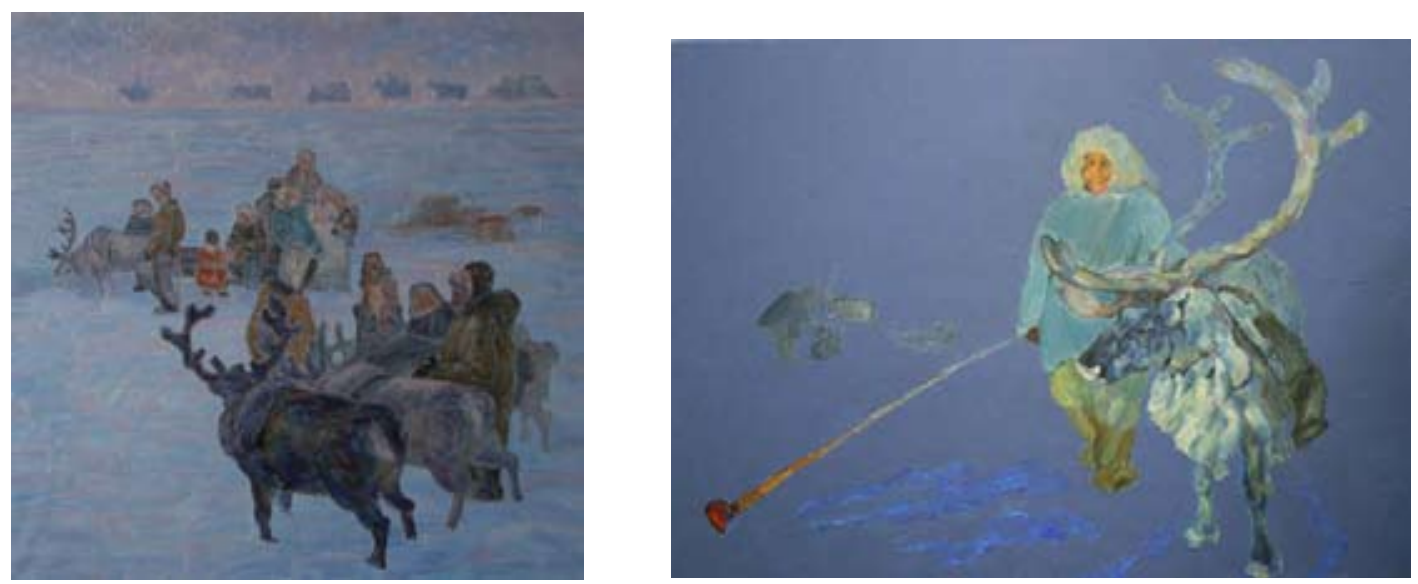

Fig. 12, 13. Osipova A.A. Cycles "The Way of Life"; "The North". 2010 


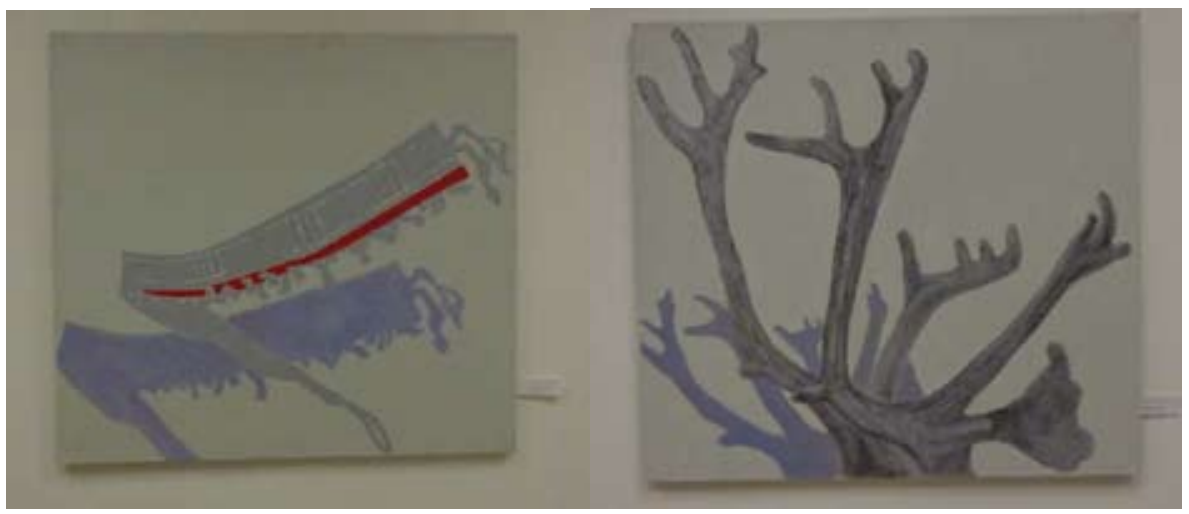

Fig. 14, 15. Nikolaeva N.V. Diptych “Reindeer”. 2013. Photo by N.N. Seredkina

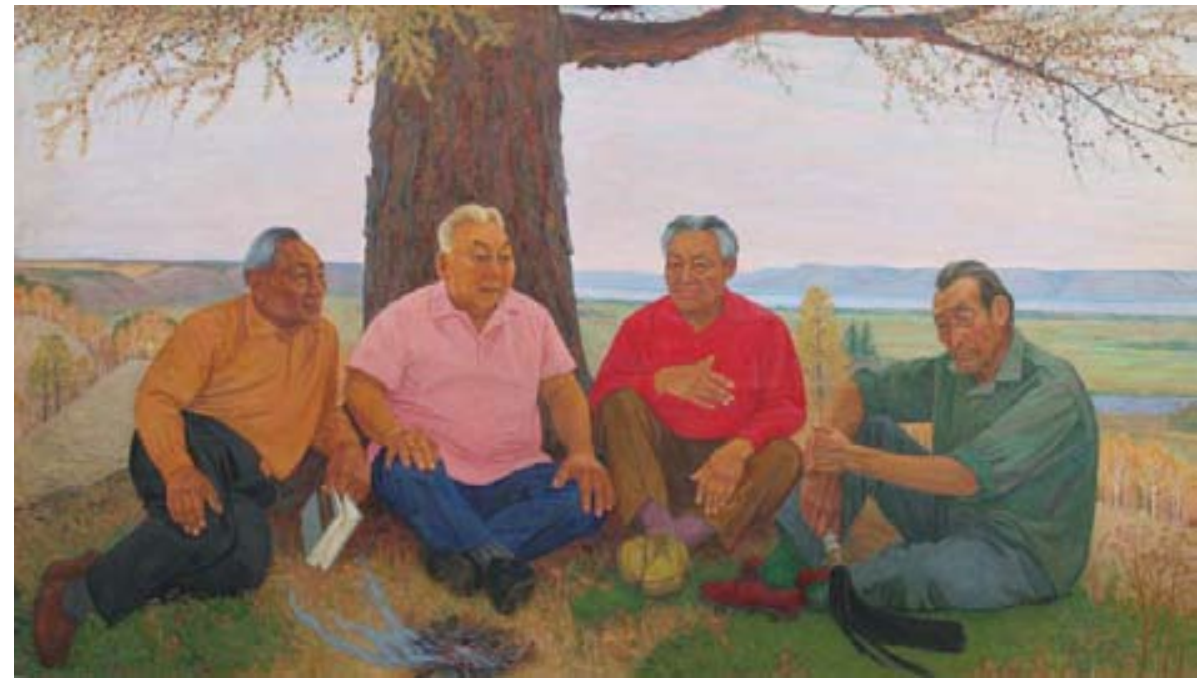

Fig. 16. A.N. Osipov "National Writers of Yakutia: N.E. Mordvinov (Amma Aggylyya), V.M. Novikov (KiunniukUrastyrov), S.R. Kulachikov (Elley), D.K. Sivtsev (Suorun Omollon)”, 1974

Writers of Yakutia: N.E. Mordvinov (Amma Aggylyya), V.M.Novikov(Kiunniuk-Urastyrov), S.R. Kulachikov (Elley), D.K. Sivtsev (Suorun Omollon)", 1974), Yu. Spiridonov "The Master of the Mom Mountains" (2007), V.G. Petrov, I.E. Kapitonov, Z.K. Kurchatova, N.P. Nikolaeva and others. Having analysed portraits by the Yakut painters, we may outline the following types: self-portraits, children's portraits, historical portraits and contemporary portraits (those of relatives, representatives of a certain craft, such as hunters, reindeer breeders, storytellers). Thus, sign and semiotic forms of portraits embody certain types of representatives of the Yakut ethnos, who follow the traditions of their culture, thereby deserving the status of "cultural heroes". This big interest towards the genre of portrait may be interpreted as a wish to demonstrate, that every personality of the ethnos is valuable and significant, notwithstanding the social status.

One of the distinctive works in the genre of portrait is a painting by A.N. Osipov "National Writers of Yakutia" (1974). 
The artistic space of the painting depicts writers, representatives of the Yakut creative intelligentsia, sitting in front of a tree trunk, in the middle of a wide meadow. Compositionally the artistic space consists of several plains, which creates the visual effect of the foreground and background on different levels. As a result, the foreground space brings the character up, above the plain surrounding them, thereby ascribing them with the characteristics of unique, outstanding persons. They are depicted motionless and quiet; there is no eye contact between them. Every one of the writers is turned in upon himself, meditating. They are creators who make up the images of the Yakut lands, forming the spiritual element of the Yakut ethnos. The characters are sitting at the base of a tree trunk: the sign interpreted as a special mission of creative people: to serve as a base for spiritual development of the Yakut culture.

The fourth group is composed by woks of still life genre. Many artists preferred working in the genre of still life. Among them there are: M.M. Nosov, S.L. Germogenova, A.S. Innokentyeva, M.M. Lukina, N.V. Nikolaeva, A.V. Chikachev, T. Shaposhnikova and others. Sign and semiotic forms of still life paintings by the Yakut painters depict the things that bear special significance

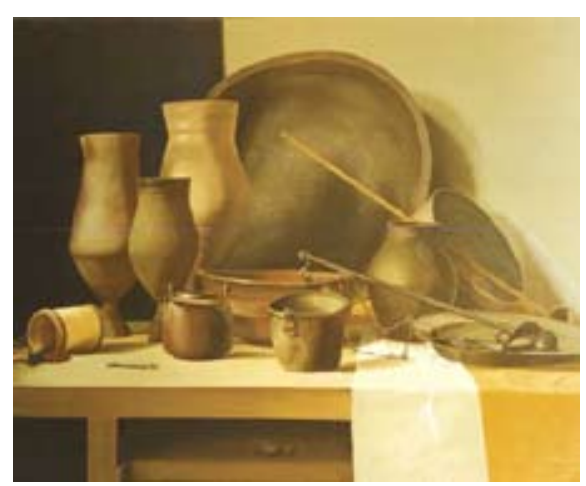

Fig. 17. Lukina M.M. Yakut Still Life with Chorons and Scales. 1998. for the ethnos. On one hand, these are the things traditionally used for religious acts and rituals, such as ritual kumis vessels ("chorons"), a compulsory attribute of Ysyakh celebration. On the other hand, these are everyday life objects, used in handcrafts.

A different aspect of still life is manifested by the modern Yakut painter T.E. Shaposhnikova. In the artistic space of her paintings certain things acquire a form of schematic silhouettes. One of the major artistic techniques used by the painter is geometrism. Often the still life objects are deprived of a contour, merging with the plain background or drifting into a different form. This artistic technique brings the viewer to participate in constructing the artistic appearance of this or that object.

The technique of dissolving the boundaries of one form in another may be interpreted in the context of the modern tendencies observed in the society today. The world of a big pluralistic society acts as an integrated space of common culture, where there is no place for strict boundaries between nations. The language of a work of art, therefore, expresses the modern tendency of interpreting micro-cultures (indigenous peoples' cultures) in the space of a macro-culture. It is worthwhile mentioning, that such a tendency of shifting from certain forms to abstractionism

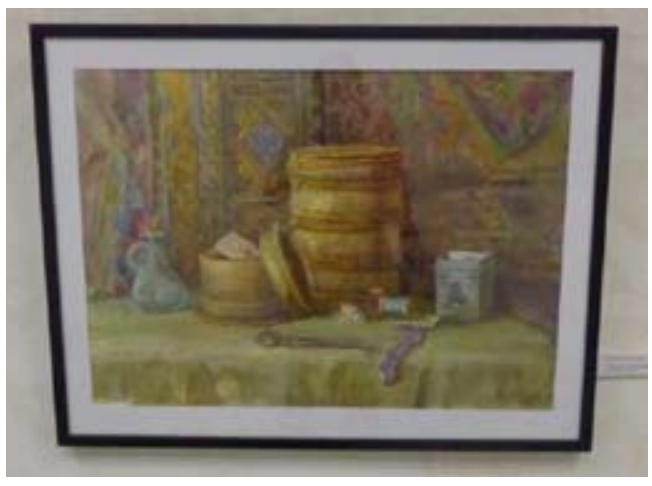

Fig. 18. Nikolaeva N.V. Needlework Accessory Boxes of Birch Bark. 2013. Photo by N.N. Seredkina 


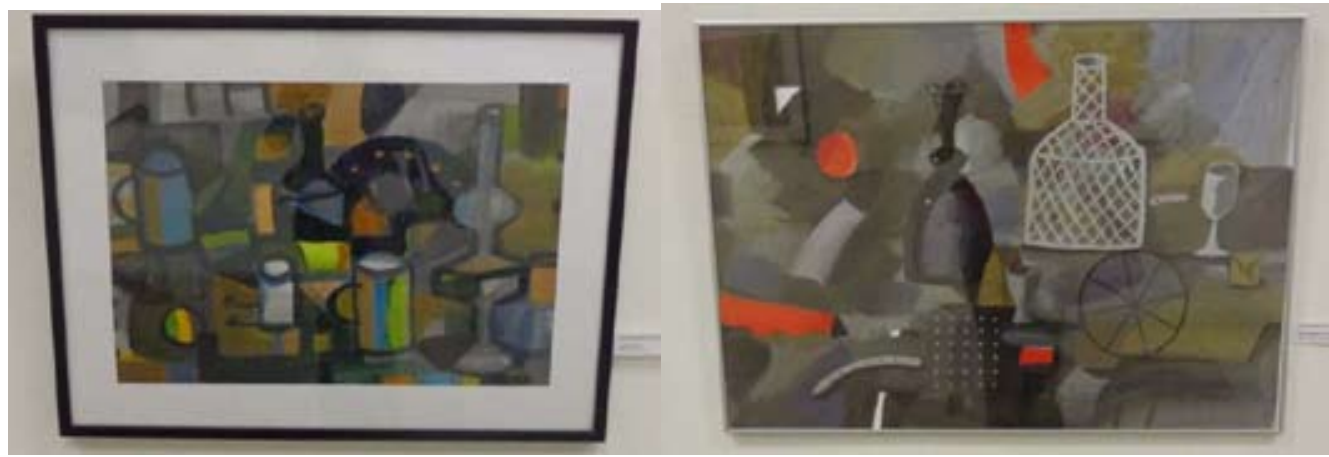

Fig. 19, 20. Shaposhnikova T.E. Still Life. 2006; Still Life with a Red Apple. 2013. Photo by N.N. Seredkina

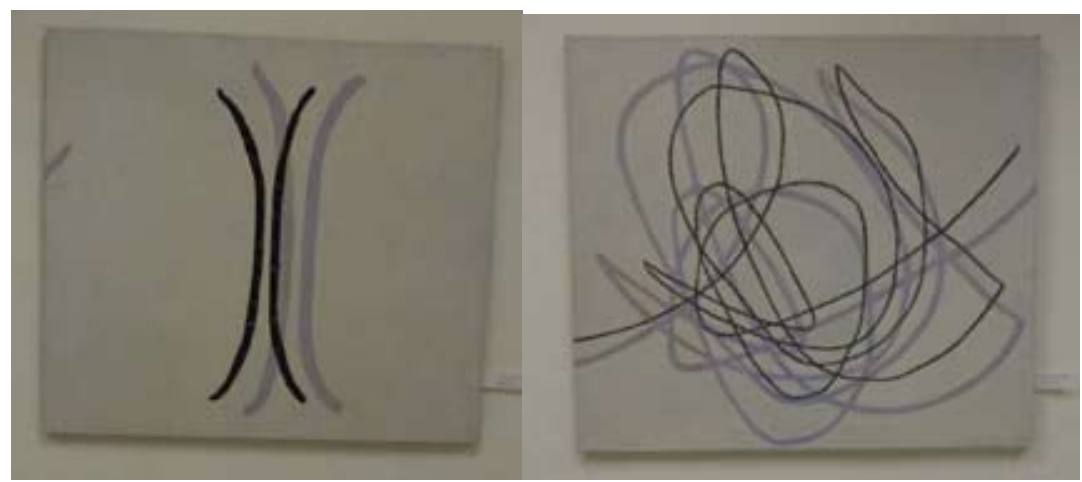

Fig. 21, 22. Nikolaeva N.V. Diptych “Chaut”. 2008. Photo by N.N. Seredkina

becomes a distinctive feature of the modern Yakut painting. One of the typical works is diptych by N.V. Nikolaeva.

In the artistic space of diptych "Chaut" by N.V. Nikolaeva the main "character" is a line. Line is the form, the artistic sign through which the artist expresses the meaning of life process, its temporal flows, which do exist, though intangible for human. According to N.V. Nikolaeva, "all temporal flows pass into one another, creating forms". These temporal flows are the past and the present, closely coexisting in the modern life of ethnocultures. The past as a cultural tradition acts as a base for modern culture. It is reviewed and re-adapted to the context of a modern person's world outlook, to the experience of world artistic culture as a whole.

\section{Conclusion}

As a result of cultural and semiotic analysis of development dynamics of the Yakut art school and works of art created by the Yakut artists, the following conclusions concerning the strategies of constructing indigenous Northern ethnicity in the symbolic "field" of art can be made.

1. The Yakut art school is a well-developed school with its history, constellation of national artists, therefore possessing the capacity to represent and construct the priority values of this ethnocultural group.

2. A distinctive feature of the Yakut art is the tendency to develop within the general stream of art history. Painters follow the traditions accepted in the world artistic society (Russian icon painting tradition, genre system, working techniques). These are the canons that have 
become a fundament for professional national art development.

3. Active participation of national artists in various exhibitions witnesses the openness of the Yakut art school to the world community. The artists do not only organize the exhibitions of their works within their regions, but take active part in the events organized on the international level. Besides exhibition activity, we remark the practice of creating artist unions (N.V. Nikolaeva, T.E. Shaposhnikova), issuing catalogues with the reproductions of national art works. In one word, the Yakut artist society is not isolated from the outside globalizing world; on the opposite, it is open for a dialogue of cultures.

4. Analysis of paintings created by the Yakut artists throughout the whole history of the Yakut art development has proved, that construction of indigenous Northern ethnicity is associated with the use of shapes, cultural sign systems in the form of traditional ethnocultural values, materialized in paintings and enriched with the whole experience of world art culture through review and readjustment to the modern world context.

5. Works by the Yakut painters were brought into a system according to the revealed ethnocultural values. We outlined the following blocks of paintings:
- paintings with sign and semiotic systems embodying the spiritual outlook fundament of the Yakut;

- aintings actualizing the idea of the way, road of life a human walks along;

- paintings representing certain types of Yakut ethnos representatives;

- paintings with sign and semiotic forms that draw the viewer's attention to the things that bear special significance in the Yakut Culture. As G.W.V. Hegel rightfully remarked, “...through this ideality, art at the same time exalts these otherwise worthless objects which, despite their insignificant content, it fixes and makes ends in themselves; it directs our attention to what otherwise we would pass by without any notice" (Hegel, 1968, p.172).

6. Of greatest interest are the modern Yakut art works, distinctive for abstracting from certain forms to geometrism and abstractionism. This technique, as a new language of communication with the viewer, fixes the tendency of reviewing the universal artistic culture in the ethnical culture context. Such neo-folklore wave creates a specific rescript, merging the modern painting tendencies with the ethnical memory.

\section{References}

1. Abramova M.A., Goncharova G.S. Stepeni etnichnosti kak osnova natsional'noy politiki [Ethnicity Degrees as the Basis for National Policy] // Sotsiologicheskie issledovaniia, 2012, 10, available at: http://www.isras.ru/socis_2012_10.html

2. Arytiunian Iu.V. Ob etnicheskikh komponentakh rossiyskoy identichnosti [On Ethnical Components of Russian Identity] // Sotsiologicheskie issledovaniia, 2009, 6, available at: www.isras. ru/socis_2009_6.html

3. Alexander J., Smith F. Sil'naia programma v kul'tursotsiologii [The Strong Program in Cultural Sociology] // Sotsiologicheskoe obozrenie, 2010, 9 (2), 11-30.

4. Bobrikhin A.A. Reprezentatsii etnicheskoy identichnosti v sovremennoy kul'ture [Ethnical Identity Representations in Modern Culture] // Mezhdunarodnyy zhurnal issledovaniy kul'tury, 2010, $1,31-36$. 
5. Bol'shakova A.Iu. Arkhetip - kontsept - kul'tura [Archtype - Concept - Culture] // Voprosy filosofii, 2010, No.7, available at: http://vphil.ru/index.php

6. Borisova A.A. Aksiologicheskie dominanty "alaasnoy kul'tury” naroda Sakha [Axiological Dominants of "Alaas Culture" of the Sakha People] // Vestnik IAGU, 2010, 4 (1), 105 - 112.

7. Bychkov V.V. Mif v prostranstve khudozestvennoy simvolizatsii [Myth in the Artistic Symbolization Space] // Voprosy filosofii, 2010, 7, available at: http://vphil.ru/index.php

8. Bychkov V.V., Man'kovskaia N.B., Ivanov V.V. Trialog. Razgovor Vtoroy oflosofii iskusstva v raznykh izmereniiakh [Trialogue. Conversation Two on the Philosophy of Art in Different Dimensions]. Moscow, IFRAN, 2009. 216 p.

9. Bychkov V.V., Man'kovskaia N.B. Iskusstvo tekhnogennoy tsivilizatsii v zerkale estetiki [Technical Civilization Art Through the Mirror of Aesthetics] // Voprosy filosofii, 2011, 7, available at: http://vphil.ru/index.php

10. Bychkov V.V. Simvolizatsiia v iskusstve kak esteticheskiy printsip [Symbolization in Art as an Aesthetic Principle] // Voprosy filosofii, 2012, № 3, available at: http://vphil.ru/index.php

11. Varnavskiy P.K. Strategii konstruirovaniia sotsiokul'turnykh granits $v$ sovremennom diskurse buriatskoy etnichnosti [Social Cultural Bounder Construction Strategies Within the Modern Discourse of the Buryat Ethnicity] // Problemy istorii, filologii, kul'tury, 2008, 20, 254-266.

12. Gartig V.O. Etnofuturizm kak otrazhenie natsional'noy identichnosti $v$ tvorchestve khudozhnikov Uralo-Povolzh'ia [Ethnofuturism As National Identity Reflection in the Works of UralVolga Region] // Vestnik Udmurtskogo universiteta, 2006, 12, 59-66.

13. Hegel G.W.F. Aesthtics. In 4 volumes. Volume 1, Moscow, Iskusstvo, 1968. P. 172.

14. Girts K. Interpretatsiia kul'tur [Interpretation of Cultures]. Moscow, Rossiyskaia politicheskaia entsiklopediia, 2004. $560 \mathrm{p}$.

15. Girts K. Iskusstvo kak kul'turnaia sistema [Art as Cultural System] // Sotsiologicheskoe obozrenie, 2010, 9 (2), 31-54.

16. Gribova E. Steve Sherwood. V poiskakh sakral'nogo: pozdne diurkgeymianskaia teoriia khudozhnika[Searching fortheSacral:LateDurkheimianTheory of Artist]//Sotsiologicheskoeobozrenie, 2010, 9(2), 92-98.

17. Davydov D. Sotsial'naia identichnost': teoriia ratsional'nogo vybora kak al'ternativnyy podkhod k kontseptualizatsii [Social Identity: Rational Selection Theory as an Alternative Approach to Conceptualization] // Sotsiologicheskoe obozrenie, 2012, 11(2), 131-142.

18. Drovizheva L.M. Gosudarstvenno-grazhdanskaia identichnost' $v$ respublikakh $v$ obscherossiyskom kontekste (Sotsiologiia i obschestvo: global'nye vyzovy i regional'noe razvitie) [State and Civilian Identity of Republics in the General Russian Context (Sociology and Society: Global Challenges and Regional Developments] // Proceedings of the IV Ordinary All-Russian Congress on Sociology. Moscow, 2012, available at: http://www.isras.ru/files/File/congress2012/part16.pdf.

19. Dukhan I.N. Filosofiia klassicheskogo $v$ iskusstve $i$ proektnoy kul'ture modernizma [Philosophy of the Classical in Art and Project Culture of Modernism] // Voprosy filosofii, 2009, № 6, available at:ttp://vphil.ru/index.php

20. Evseeva M.A. Dinamika sotsial'nogo samochuvstviia sakha i russkikh respubliki Sakha (Yakutiia) v poslednee desiatiletie (Sotsiologiia i obschestvo: global'nye vyzovy i regional'noe razvitie) [Dynamics of Social Well-Being of the Sakha and Russians Resident in the Sakha Republic (Yakutia) 
Within the Past Decade (Sociology and Society: Global Challenges and Regional Development)] // Proceedings of the IV Ordinary All-Russian Congress on Sociology. Moscow, 2012, available at: http:// www.isras.ru/files/File/congress2012/part16.pdf. - C. C. 2503-2508

21. Zhukovskiy V.I. Drevnerusskoe iskusstvo. Kranoyarsk, Siberian Federal University, 2007, $416 \mathrm{p}$.

22. Zamaraeva Iu.S. Aktual'nost' issledovaniia otnosheniia migranta i prinimaiuschey sredy $v$ sovremennoy filosofii kul'tury [Urgency of Researching the Relations of a Migrant and a Receiver Environment in the Modern Philosophy of Culture] // Nauka i sovremennost', 2010, 5-3, 96-100.

23. Zamiatin D.N. Obraz naslediia v kul'ture. Metodologicheskie podkhody $k$ izucheniiu poniatiia naslediia [Heritage Appearance in Culture. Methodological Approaches to Research of the Notion of Heritage] // Sotsiologicheskie issledovaniia, 2010, 2, available at: http://www.isras.ru/ socis_2010_02.html

24. Znanie o proshlom v sovremennoy kul'ture [Knowledge of the Past in Modern Culture] (round table proceedings) // Voprosy filosofii, 2011, available at: http://vphil.ru/index.php

25. Ivanov R.N. Krizis identichnosti v usloviiakh massovoy kul'tury [Identity Crisis Under Mass Culture Conditions] // Mir nauki, kul'tury, obrazovaniia, 4-2, 252-254.

26. Ivanova-Unarova Z.I. Traditsionnoe iskusstvo narodov Severo-Vostoka Sibiri [Traditional Art of Peoples of the Siberian North-East] (monograph). Yakutsk, Yakutsk University Press, 2005, 209 p. (torrent)

27. Ivan'ko N.A. Vital'nost' etnicheskogo v epokhu global'nogo [Vitality of the Ethnic in the Epoch of Global]//Vestnik Moskoskogo gorodskogo pedagogicheskogo universiteta. Series: Philosophy science, 2, 52-62

28. Identichnost' $i$ konsolidatsionnyy resurs zhiteley respubliki Sakha (Iakutiia). [Identity and Consolidated Resource of the Citizens of the Sakha Republic (Yakutia)]. Moscow, Institute of Sociology of Russian Academy of Science, 2012. 97 p. available at: http://www.isras.ru/inab_2012_04.html.

29. Iskusstvo Iakutii [Art of Yakutiia] (catalogue) / National Art Museum of the Sakha Republic (Yakutia); [comp. by G.A. Safronova et al.]. Yakutsk, Bichik, 2005, 121 p.

30. Istomina O.B. O tipakh etnicheskoy identichnosti [On Ethnical Identity Types] // Sotsiologicheskie issledovaniia, 2011, 11, available at: www.isras.ru/socis_2011_11.html

31. Kirko V.I., Zakharova K.N. Traditsionnaia khoziaystvennaia deiatel'nost' etnosokhraniaiuschiy obraz zhizni [Traditional Economic Activity as an Ethnopreserving Way of Life] // Arktika i Sever, 2013, 12, 24-31.

32. Kistova, A.V. Metodologicheskoe znachenie "ponimaiuschey germenevtiki" Vil'gel'ma Di'teia dlia sotsial'no-filosofskogo issledovaniia sovremennykh sotsiokul'turnykh fenomenov [Methodological Significance of "Hermeneutical Understanding" by Wilhelm Dilthey for Socio-Philosophical Research of Modern Sociocultural Phenomena] // Sovremennye problemy nauki i obrazovaniia, 2013. No.3.

33. Koptseva N.P. Filosofiia i iskusstvo: edinstvo myslitel'nogo prostranstva [Philosophy and Art: Thinking Space Integrity] (scientific notes of the Art Criticism and Culturology Department). Volume 1. Krasnoyarsk, 2000.

34. Koptseva N.P. Integratsiia gumanitarnogo obrazovaniia v Sibirskom federal'nom universitete [Integration of Humanitarian Education at Siberian Federal University] // Vysshee obrazovanie segodnia, 2007, 4, 6-8. 
35. Koptseva N.P. Teoriia $i$ praktika innovatsionnoy obrazovatel'noy programmy po esteticheskomy tsiklu distsiplin [Theory and Practice of Innovative Educational Program on the Aesthetic Disciplines] // Vysshee obrazovanie segodnia, 2007, 12, 9-13.

36. Koptseva N.P. Kul'turologicheskaia baza formirovaniia obscherossiyskoy natsional'noy identichnosti $v$ Sibirskikh regionakh Rossiyskoy Federatsii [Culturological Base of Forming the AllRussian National Identity in the Siberian Regions of the Russian Federation] // Vestnik Volgogradskogo gosudarstvennogo universiteta. Series 7. Philosophy, sociology and social technologies, 2012, 3, 11-15.

37. Koptseva N.P. Provedenie eksperimental'nogo prikladnogo kul'turnogo issledovaniia mezhkul'turnoy kommunikatsii: fokus-gruppy, lichnoe interv'iu, anketirovanie, poluchenie ekspertnogo mneniia (na material issledovaniia Krasnoiarskogo kraia) [Experimental Applied Cultural Research on Intercultural Communication: Focus Groups, Personal Interview, Survey, Expert Opinion (Based on Research of Krasnoyarsk Region)] // Sovremennye problemy nauki i obrazovaniia, 2013, 3, 410-410.

38. Koptseva N.P., Nevol'ko N.N. Vizualizatsiia etnicheskikh traditsiy $v$ zhivopisnykh $i$ graficheskikh proizvedeniiakh khakasskikh masterov [Ethnical Tradition Visualization in Painting and Graphic Works by Khakass Artists] // Iskusstvo i obrazovanie, 2012, 1, 27-45.

39. Koptseva N.P. Kul'turologicheskaia baza formirovaniia obscherossiyskoy natsional'noy identichnosti v Sibirskikh regionakh Rossiyskoy Federatsii [Culturological Basis of Forming AllRussian National Identity in the Siberian Regions of the Russian Federation] // Vestnik Volgogradskogo gosudarstvennogo universiteta. Series 7. Philosophy, Sociology and Social Technologies, 2012, 3, 11-15.

40. Koptseva N.P. Problema metodologii sovremennykh kul'turnykh issledovaniy: vozmozhnosti klassicheskoy britanskoy sotsial'noy antropologii [Methodological Problem of Modern Research of Culture: Capacities of Classical British Social Anthropology] // Gumanitarnye i sotsial'nye nauki, 2012, 4, P. 89-104.

41. Koptseva N.P., Luzan V.S. Gosudarstvennaia kul'turnaia politika v Sibirskom federal'nom okruge: kontseptsii, problemy, issledovaniia [National Cultural Policy of Siberian Federal Okrug: Concepts, Problems, Surveys] (monograph). Krasnoyarsk: SFU Press, 2012.

42. Koptseva N.P., Pimenova N.N., Seredkina N.N. Izuchenie dekorativno-prikladnogo iskusstva i traditsionnykh religiy korennykh malochislennykh narodov Severa kak faktor formirovaniia pozitivnoy obscherossiyskoy kul'turnoy identichnosti [Study on Decorative and Applied Arts, Traditional Religions of Small-Numbered Indigenous Peoples of the North as a Factor of Forming a Positive AllRussian Cultural Identity] // Pedagogika iskusstva, 2013, 2, available at: http://www.art-education.ru/ AE-magazine/new-magazine.htm

43. Koptseva N.P. Provedenie eksperimental'nogo prikladnogo kul'turnogo issledovaniia mezhkul'turnoy kommunikatsii: fokus-gruppy, lichnoe interv'iu, anketirovanie, poluchenie ekspertnogo mneniia (na material issledovaniia Krasnoiarskogo kraia) [Experimental Applied Cultural Research on Intercultural Communication: Focus Groups, Personal Interview, Survey, Expert Opinion (Based on Research of Krasnoyarsk Region)] // Sovremennye problemy nauki i obrazovaniia, 2013, 3, 410-410.

44. Koptseva N.P. Istina v filosofii Platona [Truth in Plato's Philosophy] // Filosofiia i kul'tura, 2013, 4, 429-436.

45. Koptseva N.P. Problema istiny v filosofii religii. Spetsifika kontseptualizatsii istiny $v$ buddiyskoy filosofii [Problem of Truth in the Philosophy of Religion. Specificity of Conceptualizing Truth in Buddhist Philosophy] // Filosofiia i kul'tura, 2013, 11, 1564-1573.

$$
-787-
$$


46. Koptseva, N.P., Libakova, N.M. Produktivnost' gendernogo podkhoda dlia gumanitarnykh issledovaniy [Efficiency of Gender Approach for Humanitarian Research] // Sovremennye problemy nauki i obrazovaniia, 2013, 1.

47. Koptseva N.P., Seredkina N.N. Konstruirovanie pozitivnoy etnicheskoy identichnosti $v$ polikul'turnoy sisteme [Constructing Positive Ethnic Identity Within a Policultural System] (monograph) Krasnoyarsk, Siberian Federal University, 2013. 184 p.

48. Korennye malochislennye narody Severa i Sibiri v usloviiakh global'nykh transformatsiy (na materiale Krasnoiarskogo kraia). Chast' 1. Kontseptual'nye i metodologicheskie osnovy issledovaniia. Etnokul'turnaia dinamika korennykh malochislennykh narodov Krasnoiarskogo kraia [Small-Numbered Indigenous Peoples of the North and Siberia under Global Transformations (Based on Krasnoyarsk Region Data). Volume 1. Conceptual and Methodological Basis for Research. Ethnocultural Dynamics of Small-Numbered Indigenous Peoples of Krasnoyarsk Region] (Amosov A.E., Koptseva N.P., Libakova N.M., Reznikova K.V., Sertakova K.V., Pimenova N.N., Kistova A.V. et al. Edited by N.P. Koptseva). Krasnoyarsk, Siberian Federal University Press, 2012. $640 \mathrm{p}$.

49. Krasnopol'skaia I.I., Solodova G.S. Sotsial'noe konstruirovanie etnichnosti [Social Constructing of Ethnicity] // Sotsiologicheskie issledovaniia, 2013, 12, available at: http://www.isras. ru/socis_2013_12.html

50. Krivonogov V.P. Narody Taymyra (sovremennye etnicheskie protsessy) [Peoples of the Taymyr (Modern Ethnic Processes)]. Krasnoyarsk: RIO KGPU, 2001.

51. Krivonogov V.P. Narody Taymyra $v$ nachale XXI veka [Peoples of the Taymyr in Early $21^{\text {st }}$ Century]. Krasnoyarsk: RIO KGPU, 2007.

52. Kul'tura korennykh $i$ malochislennykh narodov Severa $v$ usloviiakh global'nykh transformatsiy [Culture of Small-Numbered and Indigenous Peoples of the North Under Global Transformations] (monograph) (N.P. Koptseva, E.A. Sertakova, M.I. Il'beykina, Iu.S. Zamaraeva, N.M. Libakova, V.S. Luzan et al.) edited by N.P. Koptseva. Saint Petersburg, Eydos, 2011. 174 p.

53. Lapin N.I. Funktsional'no-orientiruiuschie klastery bazovykh tsennostey naseleniia Rossii i eio regionov [Function-Orienting Clusters of Basic Values of the Population of Russia and its Regions] // Sotsiologicheskie issledovaniia, 2010, 1, available at: http://www.isras.ru/ socis_2010_01.html

54. Libakova N.M. Modifikatsii gendernykh obrazov v rossiyskoy kul'ture kontsa XIX-nachala $X X I v v$. [Modifications of Gender Appearances in Russian Culture of the Late $19^{\text {th }}$ - Early $21^{\text {st }}$ Centuries] Dissertation for the degree of Candidate of Philosophy: 24.00.01 [Place of defence: The Yaroslav-TheWise Novgorod State University]. Krasnoyarsk, 2011, 155 p.

55. Luzan V.S. Sotsial'no-filosofskiy analiz dinamiki gosudarstvennoy kul'turnoy politiki Rossiyskoy Federatsii [Social and Philosophic Analysis of the Dynamics of National Cultural Policy of the Russian Federation], dissertation for the degree of Candidate of Philosophy: 09.00.11 [Place of defence: Siberian Federal University]. Krasnoyarsk, 2011. 170 p.

56. Luzan V.S. Konteksty ponimaniia intellektual'nogo dosuga v sovremennykh rossiyskikh issledovaniiakh [Contexts of Understanding Intellectual Leisure in Modern Russian Researches] // Vestnik Krasnoiarskogo gosudarstvennogo pedagogicheskogo universiteta im. V.P. Astaf'eva, 2013, 4 (26), 175-178. 
57. Lutsenko Iu.V. Khudozhestvenno-esteticheskoe samosoznanie khudozhnikov Iakutii na rubezhe tysiacheletiy [Artistic and Aesthetic Self-Conscience of the Yakut Artists at the Turn of Millennia], dissertation abstract. Saint Petersburg, 2009.

58. Lutsenko Iu.V. Sovremennoe izobrazitel'noe iskusstvo Iakutii: traditsii i novatorstvo [The Modern Yakut Visual Art: Traditions and Innovations] // Gumanitarnye issledovaniia v Vostochnoy Sibiri i na Dal'nem Vostoke, 2011, 1, 31-32.

59. Liusyy A.P. Skvoz' simvoly. Dialektika simvolizatsii/desimvolizatsii kak fundamental'noe osnovanie prikladnoy kul'turologii [Dialectics of Symbolizing/Desymbolizing as a Fundament of Applied Culturology] // Voprosy filosofii, 2009, available at: http://vphil.ru/index.php

60. Moskaliuk M.V. Vse, chto v serdtse. Khudozhniki Krasnoyar'ia vchera, segodnia, zavtra [All From the Heart. Artists of Krasnoyarsk Land Yesterday, Today, Tomorrow]. Krasnoyarsk: Polikor, 2010.

61. Matochkin E.P. Arkheologiia, drevnee nasledie i arkheoart Sibiri [Archaeology, Ancient Heritage and Archaeoart of Siberia] // Gumanitarnye nauki v Sibiri, 2009, 3, 7-10.

62. Matochkin E.P. Problemy preemstvennosti v narodnom iskusstve Sibiri [Succession Problems in Folk Art of Siberia] // Vestnik Cheliabinskogo gosudarstvennogo universiteta, 2009, 13, 171-173.

63. Mironova N.P. Konstruirovanie etnichnosti v tekstakh sovremennoy kul'tury (na primere respubliki Komi) [Constructing Ethnicity in Modern Culture Texts (Based on the Komi Republic)] // Chelovek. Kul'tura. Obrazovanie, 2012, 4, 102-117.

64. Narodnyy khudozhnik SSSR, deystvitel'nyy chlen Akademii khudozhestv SSSR Afanasiy NikolaevichOsipov[People's ArtistoftheUSSR, ActingMemberofAcademy of ArtsoftheUSSRAfanasiy Nikolaevich Osipov] (exhibition catalogue). Introduction and compilation by L.A. Kol'tsova. Moscow, Sovetskiy Khudozhnik, 1988.

65. Neustroeva G.G. Grafika Iakutii [Yakutia Graphics], Yakutsk, Bichik, 2005.

66. Nekhviadovich L.I. Etnicheskaia khudozhestvennaia traditsiia kak kategoriia teoreticheskoy istorii iskusstva [Ethnical Art Tradition as a Category of Theoretic Art History] // Izvestiia Altayskogo gosudarstvennogo universiteta, 2010, 2-2, 148-151.

67. Novoe buduschee Sibiri: ozhidaniia, vyzovy, resheniia [New Future of Siberia: Expectations, Challenges, Solutions] (monograph) (N.A. Bakhova, A.V. Bukharov, E.A. Viktoruk, M.I. Il'beykina et al.) (edited by O.A. Karlova, N.P. Koptseva). Electronic copy. Krasnoyarsk, Siberian Federal University, 2013.

68. Osipova O.V. Geroicheskiy epos kak element etnicheskoy identifikatsii Sakha: otsenka v obschestvennom mnenii [Heroic Epos as an Element of Ethnical Identification of the Sakha: Attitude in the Public Opinion] // Arktika i Sever, 2011, 4, 83-92.

69. Pavlova E.Iu. Etnicheskaia tema v sovremennom iksusstve i narodnye promysly Zapadnoy Sibiri [Ethnical Theme in Modern Art and Folk Crafts of the Western Siberia] // Gumanitarnye nauki v Sibiri, 2007, 3, 74-77.

70. Podoynitsyna I.I., Kuz'minov M.A. Vosproizvodstvo natsional'noy kul'tury narodov Sakha v sovremennykh usloviiakh [Reproduction of the National Culture of the Sakha Peoples Under Modern Conditions] // Sotsiologicheskie issledovaniia, 2013, 12, available at: http://www.isras.ru/ socis_2013_12.html

71. Pozdniakova O.A., Reznikova K.V. Osobennosti sub'ektov khudozhestvennoy kinokommunikatsii [Peculiarities of Artistic Cinema Communication Subjects] // Sovremennye problemy nauki i obrazovaniia, 2013, 4. 
72. Popytaev D.S. Sokhranenie i razvitie etnokul'turnogo mnogoobraziia indigennykh narodov: opyt Rossiyskoy Federatsii [Preservation and Development of Indigenous Peoples' Ethnocultural Diversity: Experience of the Russian Federation] // Vestnik Rossiykoy natsii, 2013, 6(6), 105-118.

73. Rashkovskiy E.B. Mnogoznachnyy fenomen identichnosti: arkhaika, modern, postmodern [Ambiguous Identity Phenomenon: Archaic, Modern, Post-Modern] // Voprosy filosofii, 2011, №6, available at: http://vphil.ru/index.php

74. Reznikova, K.V. Sotsial'noe konstruirovanie obschenatsional'noy identichnosti v Rossiyskoy Federatsii [Social Modelling of All-National Identity in the Russian Federation]: thesis of dissertation for the degree of Candidate of Philosophy. Krasnoyarsk, 2012. 20 p.

75. Reznikova, K.V.Znachenie kinematografa dlia formirovaniia obscherossiyskoynatsional'noy identichnosti [Role of Cinematograph in Forming the All-Russian National Identity] // Sovremennye problemy nauki i obrazovaniia, 2013. No.3, P. 416.

76. Romanova E.N., Ignatyeva V.B. Yakutskiy natsional'nyy prazdnik ysyakh $v$ situatsii perekhoda: istoricheskiy mif, etnokul'turnyy obraz i sovremennyy prazdnichnyy narrativ [Yakut National Ysyakh Celebration in the Situation of Transition: Historical Myth, Ethnocultural Appearance and Modern Festive Narrative] // Etnografichsekoe obozrenie, 2011, 4, 29-40.

77. Sabirova A.M. Etnichnost'v narodnoy kul'ture [Ethnicity in Folk Culture] // Kul'turnaia zhizn' Iuga Rossii, 2009, No.3, 129-132.

78. Semenova A.A. Vizual'naia kul'tura modernizirovannogo sotsiuma [Visual Culture of Modernized Society] // Vestnik Volgogradskogo gosudarstvennogo universiteta. Series 7. Philosophy, sociology and social technology, 2012, 3, 141-149.

79. Semenova A.A., Gerasimova A.A. Osobennosti tvorcheskogo metoda Sergeia Anufrieva [Peculiarities of Creative Method by Sergei Anufriev] // Sovremennye problemy nauki i obrazovaniia, 2013, 2, 542 .

80. Semenova A.N. Kollektivnaia dukhovnost' kak ob'ektivnoe osnovanie natsii i etnichnosti [Collective Spirituality as Objective Substantiation for Nation and Ethnicity] // Lichnost'. Kul'tura. Obschestvo, 2009, 11(4), 409-416.

81. Seredkina N.N. Pravoslavnye obrazy v khudozhestvennoy etnokul'ture sovremennoy Sibiri [Orthodox Appearances in Artistic Ethnoculture of Modern Siberia] // Sovremennye problemy nauki i obrazovaniia, 2013, 2013, 3, available at: http://www.science-education.ru/109-9609

82. Sertakova E.A. Funktsionirovanie proizvedeniy iskusstva v seti [Functioning of Art Works in the Internet] // Nauka i sovremennost', 2010, 3-1, 64-68.

83. Sertakova E.A. Kul'turnaia geografiia A. Lefevra v svete gumanitarnykh issledovaniy sotsial'nogo prostranstva goroda [Cultural Geography of $\mathrm{H}$. Lefebvre in the Context of Humanitarian Research of Urban Social Space] // Teoriia i praktika obschestvennogo razvitiia, 2012, 3, 24-26.

84. Sertakova E.A. Issledovanie "goroda" $v$ klassichskikh kontseptsiiakh zarubezhnykh uchenykh [Research of a "City" in Classic Concepts of Foreign Scholars] // Sovremennye problemy nauki i obrazovaniia, 2013, 4, 381.

85. Sivtsev E., Parnikov V., Rakhleeva M. Vystavka proizvedeniy khudozhnikov-grafikov Iakutii [Exhibition of Yakut Graphic Artists] (catalogue). Moscow, Sovetskiy khudozhnik, 1992, 32 p.

86. Sivtseva E. Obraz Bogomateri v iakutskikh ikonakh [Appearance of Holy Virgin in Yakut Icons], available at: www. ilin-yakutsk.narod.ru 
87. Smirnova A.G. Formirovanie tolerantnoy lichnosti sredstvami kul'tury. Kul'turologicheskoy aspect [Forming a Tolerant Personality by Means of Culture. Culturological Aspect] // Problemy sovremennoy nauki, 2012, 4, 25-46.

88. Spirova E.M. Simvol kak poniatie filosofskoy antropologii [Symbol as a Notion of Philosophic Anthropology] // Voprosy filosofii, 2012, 3, available at: http://vphil.ru/index.php

89. Skurtu N.P. Iskusstvo i kartina mira [Art and Worldview]. Kishinev, Shtiintsa, 1990. 88 p.

90. Struchkova N.A. Ispol'zovanie istoriko-etnograficheskikh dannykh v postanovke iakutskikh tantsev [Using Historical and Ethnographic Data in Yakut Dance Production] (Proceedings of All-Russia Conference of Young Scientists). Edited by M.L. Berezhnova. Omsk, OmGPU, 2002, 155-159.

91. Tenbruck F. Reprezentativnaia kul'tura [Representative Culture] // Sotsiologicheskoe obozrenie, 2013, 12 (3), 93-120.

92. Timofeeva V.V. Traditsionnaia kul'tura naroda Sakha v vospriiatii $i$ tvorchestve pervykh khudozhnikov Iakutii [Traditional Culture of the Sakha People Perceived and Depicted by First Yakut Artists] (Proceedings of the IV Regional Scientific Symposium, September 25-28 2003, Ulan-Ude), 2003, Volume I, 293-299.

93. Timofeeva V.V. Obraz mira v zhivopisi i grafike Iakutii XX veka [World Appearance in the $20^{\text {th }}$ Century Yakut Painting and Graphics] (dissertation). Moscow, 2006.

94. Farkhatdinov N. Sotsiologiia iskusstva bez iskusstva. Industrial'naia metafora $v$ sotsiologicheskikh issledovaniiakh iskusstva [Art Sociology Without Art. Industrial Metaphor in Sociological Research of Art]// Sotsiologicheskoe obozrenie, 2008, 7(3), 55-69.

95. Farkhatdinov N. Avtonomiia zhivopisi: or polia khudozhestvennogo proizvodstva $k$ rame kartiny [Painting Autonomy: From Field of Artistic Production to Painting Frame] // Sotsiologicheskoe obozrenie, 2010, 9 (2), 55-74.

96. Farkhatdinov N. Robert Uitkin. "Razzhevyvaia” Klementa Grinberga: abstraktsiia $i$ dva lika modernizma [Robert Uitkin. "Handfeeding" Clement Greenberg: Abstraction and Two Faces of Modernism] // Sotsiologicheskoe obozrenie, 9 (2), 81-86.

97. Fedotova V.G. Edinstvo i mnogoobrazie kul'tur v usloviiakh globalizatsii [Integrity and Diversity of Cultures Under Globalization] // Voprosy filosofii, 2011, 9, available at: http://vphil.ru/ index.php

98. Fen' E. Ron Ayerman. K sotsiologii iskusstva, orientirovannoy na smysl [Ron Eyerman. To Sociology of Sense-Oriented Art] // Sotsiologicheskoe obozrenie, 9 (2), 75-80.

99. Chistiakova A. Dzhuliia Chi Zhan'. Smysl stilia: postmodernizm, demistifikatsiia i dissonans v kitayskom avangardnom iskusstve posle sobytiy na ploschadi Tian'an'men' [Julia Chi Zhang. Sense of Style: Post-Modernism, Demistification and Dissonance in Chinese Avant-Guarde Art After the Tiananmen Square Events] // Sotsiologicheskoe obozrenie, 9 (2), 87-91.

100. Shabaev Iu.P. Narody evropeyskogo Severa Rossii: polozhenie, spetsifika identichnosti [Peoples of the European North of Russia: Position, Identity Peculiarities] // Sotsiologicheskie issledovaniia, 2011, 2, available at: http://www.isras.ru/socis_2011_02.html

101. Shabaev Iu.P. Kul'turnyy apokalipsis ili grazhdanskaia konsolidatsiia? [Cultural Apocalypse or Civil Consolidation?] // Sotsiologicheskie issledovaniia, 2013, 3, available at: http:// www.isras.ru/socis_2011_02.html

$$
-791-
$$


102. Sharacheva R.M. Natsional'no-kul'turnoe ob'edinenie kak pole "voobrazheniia” etnosa [National and Cultural Association as a Field of the Ethnos' "Imagination"] // Analitika kul'turologii, 2008, 12, 111-123.

103. Shelling F.V. Filosohiia iskusstva [Philosophy of Art]. Moscow, Mysl', 1966. 496 p.

104. Shtan'ko M.A. "Modeli mira" kak forma otrazheniia etnichnosti ["World Models" as a Means of Ethnicity Reflection] // Izvestiia Tomskogo politekhnicheskogo universiteta, 2010, 317 (6), 218-223.

105. Iusupov I.F. Natsional'noe iskusstvo kak etnicheskiy identifikator lichnosti [National Art as an Ethnical Identifier of a Personality] // Vestnik Bashkirskogo universiteta, 2007,12 (1), 217-218.

\title{
Культурно-семиотические стратегии конструирования индигенной северной этничности в искусстве
} (на примере якутской художественной школы)

\author{
Н.Н. Середкина \\ Сибирский федеральный университет \\ Россия, 660041, Красноярск, пр. Свободньій, 79
}

В статье исследуются культурно-семиотические стратегии конструирования индигенной северной этничности в искусстве на основе изучения динамики развития якутской художественной школы и анализа живописных произведений мастеров данной иколь.Определена специфика каждого из периодов становления якутского искусства, выявлена тенденция развития национальной иколь в русле общего потока истории искусства. Предложена авторская систематизация живописных произведений якутских художников. Произведения сгруппированы по тематике изображения. Это картины, культурно-семиотические формы которых воплощают духовную мировоззренческую основу якутов; произведения, репрезентирующие идею пути, дороги жизни, по которой идет человек;портреты, визуальные образы которых представляют определенные типь культурных героев; натюрморты, которые по своей жанровой специфике репрезентируют особо значимые для якутской культуры вещи. Отмечен вектор развития современного якутского искусства, направленный на переосмысление и адаптацию этнической памяти народа к новому контексту глобализирующегося мира.

Ключевые слова: культурно-семиотические стратегии, конструирование, индигенная северная этничность, национальное искусство, якутское изобразительное искусство, якутские художники, якутская художественная икола, этнокультурные иенности.

Научная специальность: 24.00.00 - культурология, 17.00.00-искусствоведение. 